\title{
Polypyrrole Coating Doped with Dihydrogenophosphate Ion to Protect Aluminium Against Corrosion in Sodium Chloride Medium
}

\author{
José Inácio Martins, ${ }^{*, a}$ Lenka Diblikova, ${ }^{b}$ Mohammed Bazzaoui ${ }^{a, c}$ and M.C. Nunes ${ }^{a}$ \\ ${ }^{a}$ Departamento de Engenharia Química, Faculdade de Engenharia, Universidade do Porto, \\ Rua Roberto Frias, 4200-465 Porto, Portugal \\ ${ }^{b}$ Institute of Chemical Technology Prague, Technická 5, 16628 Praha 6, Czech Republic
}

${ }^{c}$ Equipe de Chimie de Coordination, Laboratoire des Matériaux et Environnement, Département de Chimie, Faculté des Sciences, Université Ibnou Zohr, B.P. 28/S, Cité Dakhla 8000 Agadir, Morocco

\begin{abstract}
A electrodeposição do polipirrole (PPy) sobre alumínio em soluções de ácido fosfórico foi obtida através de técnicas potenciodinâmicas, potenciostáticas e galvanostáticas. O comportamento do alumínio revestido com polipirrole em meio de cloreto de sódio foi investigado através do potencial de circuito aberto e espectroscopia de impedância electroquímica. É proposto um mecanismo para explicar o efeito benéfico do íon dihidrogenofosfato na passivação do alumínio.
\end{abstract}

\begin{abstract}
The electrodeposition of polypyrrole (PPy) on aluminium electrodes has been achieved in phosphoric acid medium by using potentiodynamic, potentiostatic and galvanostatic techniques. The corrosion behavior of polypyrrole on aluminium in sodium chloride medium has been investigated by open circuit potential and electrochemical impedance spectroscopy. A mechanism to explain the beneficial effect of PPy-doping dihydrogenophosphate ion in the passivation of aluminium is proposed.
\end{abstract}

Keywords: polypyrrole, phosphate, aluminium, corrosion, sodium chloride

\section{Introduction}

Aluminium is the second most used material after iron in packaging, shipbuilding, transportation, construction industry, and has an unfungible role in aerospace technology. Its interesting properties, such as low density, high strength and recyclability, attract many modern industry teams for their economic and ecological benefits. ${ }^{1-3}$

Aluminium and its alloys exposed to air are naturally covered by an oxide film. This layer is heterogeneous and does not supply adequate protection against corrosion. An anodizing treatment improves its corrosion resistance. This process is usually carried out in acidic aqueous media like sulphuric, oxalic, tartaric, boric, chromic and phosphoric. ${ }^{4-7}$

The anodic coatings have a duplex structure: a thick porous outer layer (PL) separated from the metal by a thin non-porous layer called the barrier layer (BL). The $\mathrm{PL}$ is composed by hexagonal cells in a honeycomb

*e-mail: jipm@fe.up.pt arrangement, and is $c a .10^{3}-10^{4}$ times thicker than the BL. Its porous structure makes them sensitive to aggressive environments, which may be reduced by a sealing process. ${ }^{8-10}$ An appropriate selection of the electrolyte and film-forming conditions enables the control of topography and morphology of PL and BL, as well as up-take of electrolytes species, allows tailor-making of anodic films for particular applications. ${ }^{11}$ As an example, anodic films with a columnar cell structure may be obtained by phosphoric acid anodizing (PAA) under the following

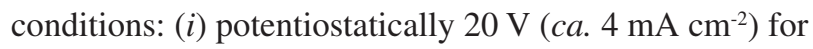
$20 \mathrm{~min}$ at $20{ }^{\circ} \mathrm{C}$ in $10 \mathrm{wt} . \% \mathrm{H}_{3} \mathrm{PO}_{4}$ : the pore and cell wall dimensions were estimated in the range of $30-50 \mathrm{~nm}$ and $15-25 \mathrm{~nm}$, respectively; ${ }^{12}$ (ii) galvanostatically $3.5 \mathrm{~mA} \mathrm{~cm}^{-2}$ for $600 \mathrm{~s}$ at $15^{\circ} \mathrm{C}$ in $0.4 \mathrm{~mol} \mathrm{~L}^{-1} \mathrm{H}_{3} \mathrm{PO}_{4}$ : the pores diameters ranged between $100-170 \mathrm{~nm}$, but increasing the temperature to $25^{\circ} \mathrm{C}$, the pore diameter is slightly reduced to an average of $c a .100 \mathrm{~nm}$, and to $35^{\circ} \mathrm{C}$ the porous, structure appears as a very open honeycomb like array with a pore diameter of about $50 \mathrm{~nm} \cdot{ }^{13}$ The morphology of PAA films gives them excellent adhesion properties. 
The main anodic reaction during the anodization process is related with the alumina production:

$2 \mathrm{Al}+3 \mathrm{H}_{2} \mathrm{O} \rightarrow \mathrm{Al}_{2} \mathrm{O}_{3}+6 \mathrm{H}^{+}+6 \mathrm{e}^{-}$

During PAA, the $\mathrm{PO}_{4}^{3-}$ ions remain unaffected by high field and migrate inwards at a rate less than that of $\mathrm{O}^{2-} / \mathrm{OH}^{-}$ions, and consequently the reaction between $\mathrm{Al}^{3+}$ and $\mathrm{PO}_{4}^{3-}$ also occurs at the film-electrolyte interface.

$\mathrm{Al}^{3+}+\mathrm{PO}_{4}^{3-} \rightarrow \mathrm{AlPO}_{4}$

These anodic films present the following average composition: $\mathrm{Al}_{2} \mathrm{O}_{3.17 \pm 0.02} \mathrm{P}_{0.72 \pm 0.06}\left(\mathrm{Al}_{2} \mathrm{O}_{2.99 \pm 0.04} 0.074 \pm 0.006\right.$ $\left(\mathrm{AlPO}_{4}\right)$ ). The current efficiency in PAA is $c a .54 \%$ of that obtained in neutral electrolytes, which means that the Pilling-Bedworth ratio falls from 1.71 to $c a$. 0.91 . Thus, the planarity of alumina film surface becomes unstable with respect to perturbations and the film thickness remains under tensile stress. ${ }^{14}$ The thickness of BL is proportional to the anodizing voltage by ratio $1.05 \mathrm{~nm} \mathrm{~V}^{-1},{ }^{15}$ and the pore per volt ratio decreases from $5.9 \times 10^{9}$ to $1.8 \times 10^{8}$ pores $\mathrm{cm}^{-2} \mathrm{~V}^{-1}$, respectively, for phosphoric acid solutions 1.5 and $0.2 \mathrm{~mol} \mathrm{~L}^{-1} .16$

Considerable evidence shows that the PPy coatings enhance the corrosion resistance of metals. ${ }^{17-19}$ The oxide/hydroxide passive film on aluminium renders difficult the pyrrole (Py) electropolymerization on its surface. However, some important results were meanwhile obtained by several researches in organic and aqueous media. ${ }^{20-29}$

The PPy electrosynthesized on aluminium in aqueous medium is a bilayer-film composed by a barrier-type $\mathrm{Al}_{2} \mathrm{O}_{3}$ and an electronically conducting PPy film..$^{22,28,29}$ The formation of $\mathrm{Al}_{2} \mathrm{O}_{3}$ proceeds at two interfaces, namely at the $\mathrm{Al} / \mathrm{Al}_{2} \mathrm{O}_{3}$ and $\mathrm{Al}_{2} \mathrm{O}_{3} / \mathrm{PPy}$. The mechanism of this process is the following: (i) the $\mathrm{Al}^{3+}$ is generated at $\mathrm{Al} / \mathrm{Al}_{2} \mathrm{O}_{3}$ interface and (ii) the obtained cations migrate through growing $\mathrm{Al}_{2} \mathrm{O}_{3}$ layer toward the solution, while oxide ions $\left(\mathrm{O}^{2-}\right)$ migrate toward the aluminium electrode. ${ }^{30}$ The initial $\mathrm{Al}_{2} \mathrm{O}_{3}$ layer contains cracks on which its hydrophilic wall is likely attached to the hydrophilic groups of supporting electrolyte. This compound forms a micelle at the surface of the wall of the cracks producing a hydrophobic domain with a highly concentration of pyrrole. It is in these cracks that pyrrole is electropolymerized to form electronically conducting paths of PPy, which is extended from the Al electrode to the surface of the $\mathrm{Al}_{2} \mathrm{O}_{3}$ layer. Therefore, the porous anodic film from PAA is a keying layer to promote the electrosynthesis of an adherent PPy coating on aluminium. From a standpoint of corrosion, if the BL is damaged, a release of phosphate from the polymer can repassivate the substrate. This work reports the anticorrosive properties of the PPy coatings obtained from phosphoric acid solutions on aluminium in sodium chloride aqueous medium.

\section{Experimental}

Pyrrole monomer (Aldrich) was distilled under nitrogen, and phosphoric acid (85\%, Pronalab) and sodium chloride (99.8\%, Sigma) were used as received. Water was distilled twice before use.

The electrochemical experiments were performed in a one-compartment cell with three electrodes connected to Autolab model PGSTAT20 potentiostat/galvanostat with pilot integration controlled by GPES 4.4 software or to Voltalab 80 Model PGZ 402 run by Voltamaster 4 software. The aluminium (99\%) rods embedded in epoxy resin $\left(0.8 \mathrm{~cm}^{2}\right.$ area $)$ and rectangular sheets $\left(8 \mathrm{~cm}^{2}\right.$ area) were used as working electrodes. The sheet samples were used to calculate the PPy thickness, and the cylindrical in remaining tests. The electrodes were mechanically polished with sandpapers 200, 600 and 1000 or 4000 mesh, and rinsed in water and acetone before each electrochemical experiment. Following this pretreatment, the electrode was immediately transferred to the electrochemical cell. A stainless-steel plate was used as auxiliary electrode. All potentials were measured vs. an $\mathrm{Ag} / \mathrm{AgCl}\left(0.1 \mathrm{~mol} \mathrm{~L}^{-1} \mathrm{KCl}\right)$ reference electrode.

Polypyrrole was electrosynthesized from $0.1 \mathrm{~mol} \mathrm{~L}^{-1}$ phosphoric acid aqueous solutions with $0.5 \mathrm{~mol} \mathrm{~L}^{-1}$ pyrrole by potentiodynamic, galvanostatic and potentiostatic techniques.

Electrochemical corrosion measurements by open circuit potential (OCP), applied current density in the range of $0.1-10 \mathrm{~mA} \mathrm{~cm}^{-2}$ during $5 \mathrm{~min}$ (AAS analysis of $\mathrm{Al}^{3+}$ with EAAGBC 932 ABPLUS equipment), and electrochemical impedance spectroscopy (EIS) were performed at room temperature in $3 \% \mathrm{NaCl}$ solution without stirring. The Nyquist plots were recorded at instantaneous open circuit potentials, in the frequency range from $3.2 \times 10^{4}$ to $10^{-2} \mathrm{~Hz}$ with $5 \mathrm{mV}$ signal perturbation.

\section{Results and Discussion}

Electrochemical behavior of aluminium in phosphoric acid without and with pyrrole

The polarization of $\mathrm{Al}$ in $0.1 \mathrm{~mol} \mathrm{~L}^{-1} \mathrm{H}_{3} \mathrm{PO}_{4}$ aqueous solution with and without Py $\left(0.5 \mathrm{~mol} \mathrm{~L}^{-1}\right)$ has been achieved using cyclic voltammetry by scanning the potential between -1 and $2 \mathrm{~V} v s$. $\mathrm{Ag} / \mathrm{AgCl}$. The first scans of both cyclic voltammograms are presented in Figure 1. The current-potential curve for $\mathrm{Al}$ in solution free of 
monomer is characterized by an anodic wave beginning at $-0.85 \mathrm{~V}$ vs. $\mathrm{Ag} / \mathrm{AgCl}$ and the current density attains a plateau of $1.5 \mathrm{~mA} \mathrm{~cm}^{-2}$ that remains stable in value for the following forward sweeping, which is associated with the $\mathrm{Al}_{2} \mathrm{O}_{3}$ formation. In the backward scan, the current falls down indicating the maintenance of the passive film. The passivation film is the result of the formation of $\mathrm{Al}(\mathrm{OH})_{3}$, $\mathrm{Al}_{2} \mathrm{O}_{3}$ and $\mathrm{Al}\left(\mathrm{PO}_{4}\right)$, according to the $\mathrm{X}$-ray photoelectron spectroscopy (XPS) analysis performed on the substratum, in agreement with the reported literature. ${ }^{31}$

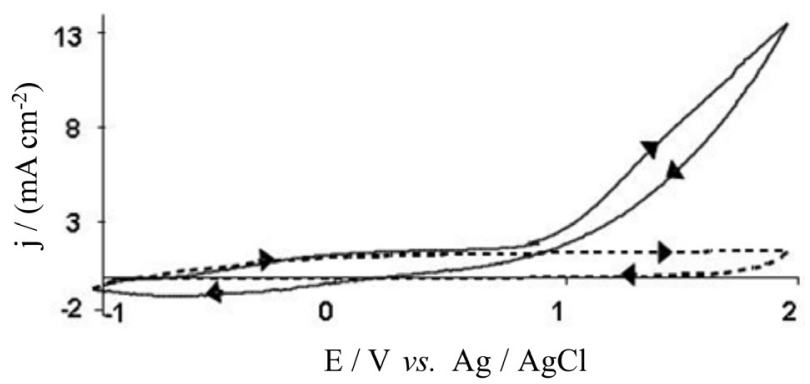

Figure 1. First scans of cyclic voltammograms of aluminium polarized in $0.1 \mathrm{~mol} \mathrm{~L}^{-1} \mathrm{H}_{3} \mathrm{PO}_{4}(--)$ and in $\left\{0.1 \mathrm{~mol} \mathrm{~L}^{-1} \mathrm{H}_{3} \mathrm{PO}_{4}+0.5 \mathrm{~mol} \mathrm{~L}^{-1} \mathrm{Py}\right\}$ (-). Scan rate: $100 \mathrm{mV} \mathrm{s}^{-1}$.

After adding the pyrrole to the phosphoric acid medium, the shape of the voltamperometric curve becomes different from that without monomer. The oxidation wave shifts to ca. $0.8 \mathrm{~V}$ vs. $\mathrm{Ag} / \mathrm{AgCl}$ showing the pyrrole oxidation. In the backward scan, a broad peak at $-0.5 \mathrm{~V}$ vs. $\mathrm{Ag} / \mathrm{AgCl}$ corresponds to the polypyrrole reduction. At the end of the experiment, a homogeneous PPy layer is formed on the Al electrode. According to the equilibrium constants of proton-transfer reactions for phosphoric acid, ${ }^{32}$ the $\mathrm{H}_{3} \mathrm{PO}_{4}$ and $\mathrm{H}_{2} \mathrm{PO}_{4}^{-}$are practically the existing species to the $\mathrm{pH}$ of the electrolyte. Therefore, only $\mathrm{H}_{2} \mathrm{PO}_{4}^{-}$contributes to doping the PPy, although the dominant phosphorus specie is the $\mathrm{H}_{3} \mathrm{PO}_{4}$.

Galvanostatic and potentiostatic electrodeposition of PPy on aluminium electrode

The electrodeposition of PPy on aluminium has been achieved using chronopotentiometric and chronoamperometric techniques in $0.1 \mathrm{~mol} \mathrm{~L}^{-1}$ phosphoric acid solution containing $0.5 \mathrm{~mol} \mathrm{~L}^{-1}$ pyrrole monomer during $15 \mathrm{~min}$.

Figure 2 shows the potential-time curves obtained by applying different current densities from 1 to $10 \mathrm{~mA} \mathrm{~cm}^{-2}$. The applied current density of $1 \mathrm{~mA} \mathrm{~cm}^{-2}$ is not enough to obtain a homogeneous PPy film, and the electrode surface is covered only by small black PPy islands after the polarization.
The formation of homogeneous PPy films starts at $3 \mathrm{~mA} \mathrm{~cm}^{-2}$ where the potential attains a value higher than the potential corresponding to the monomer oxidation. At this current density, the potential does not reach a plateau that means a change in the layer of aluminium oxide. The thickness of the coating was estimated by the following expression:

$\theta=\frac{\Delta \mathrm{mF}+\left(\frac{\tau_{\text {ind }} \mathrm{IM}_{\mathrm{Al}}}{3}\right)}{\mathrm{FA} \rho}$

where $\mathrm{F}$ is the Faraday's constant, A the electrode surface area, $\rho$ the polymer density $\left(\rho_{\mathrm{PPy}}=1.5 \mathrm{~g} \mathrm{~cm}^{-3}\right), \Delta \mathrm{m}$ the experimental mass difference between the blank and the coated electrode, I the polarization current, $\mathrm{M}_{\mathrm{Al}}$ the atomic weight of the aluminium and $\tau_{\text {ind }}$ is the induction time during which the electrode dissolves. The data gathered in Table 1 show that the higher is the applied current, the thicker is the PPy film obtained and better the Faradaic yield.

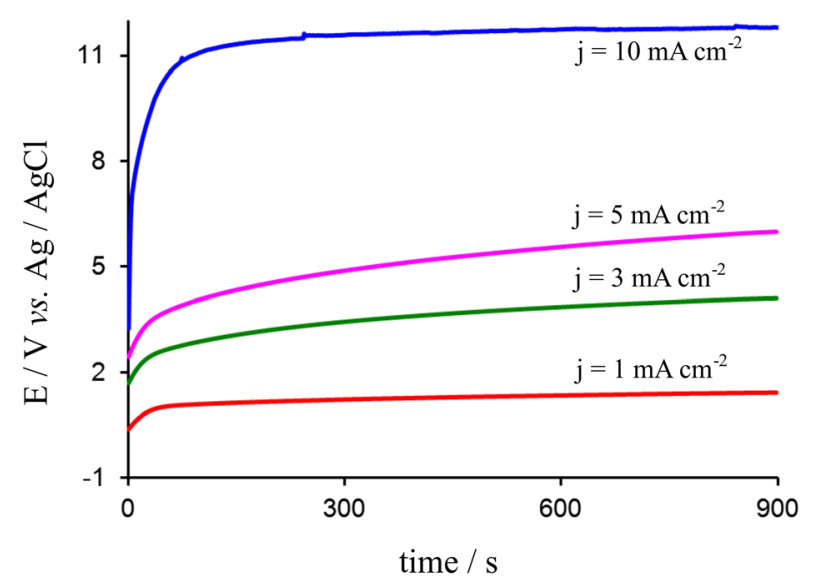

Figure 2. Chronopotentiometric curves of PPy electrodeposition on aluminium in $\left\{0.1 \mathrm{~mol} \mathrm{~L}^{-1} \mathrm{H}_{3} \mathrm{PO}_{4}+0.5 \mathrm{~mol} \mathrm{~L}^{-1} \mathrm{Py}\right\}$ at different applied current densities: $1,3,5$ and $10 \mathrm{~mA} \mathrm{~cm}^{-2}$.

Table 1. Faradaic yield and thickness of the PPy coatings deposited on $\mathrm{Al}$ electrode at different current densities during $15 \mathrm{~min}$

\begin{tabular}{lccc}
\hline $\mathrm{j} /\left(\mathrm{mA} \mathrm{cm}^{-2}\right)$ & $\Delta \mathrm{m} / \mathrm{mg}$ & $\gamma / \%$ & $\theta / \mu \mathrm{m}$ \\
\hline 3 & 7.3 & 97 & 7.5 \\
5 & 11.6 & 98 & 12.4 \\
10 & 23.2 & 98 & 24.8 \\
\hline
\end{tabular}

These results are expected since the galvanostatic curves are characterized by a small induction time that is in line with the BL developed on aluminium surface.

In the case of potentiostatic mode (applied potential since 0.6 to $1.2 \mathrm{~V} v s$. $\mathrm{Ag} / \mathrm{AgCl}$ ), Figure 3, only with a potential equal or higher than $0.8 \mathrm{~V} v s$. $\mathrm{Ag} / \mathrm{AgCl}$ it 
is observed the Py electropolymerization. This is in agreement with the pyrrole oxidation potential wave observed during the potentiodynamic electrosynthesis. The chronoamperometric curves initially show a decrease in current density, and then the nucleation and growth of PPy on aluminium take place. The decay portion of transient is related with the BL growth. The current density plateau increases with rising potential, and consequently the PPy thickness increases. PPy/phosphate films deposited on gold electrodes at $0.700 \mathrm{~V} v$ s. SCE with $800 \mathrm{~nm}$ thickness $^{33}$ revealed a composition approximately with $81 \%$ PPy, $18 \%$ dihydrogenophosphate anions and less than $1 \%$ of water. Since the amount of water on the film depends on the porosity of the polymer structure, one can conclude that these layers are compact with small pores.

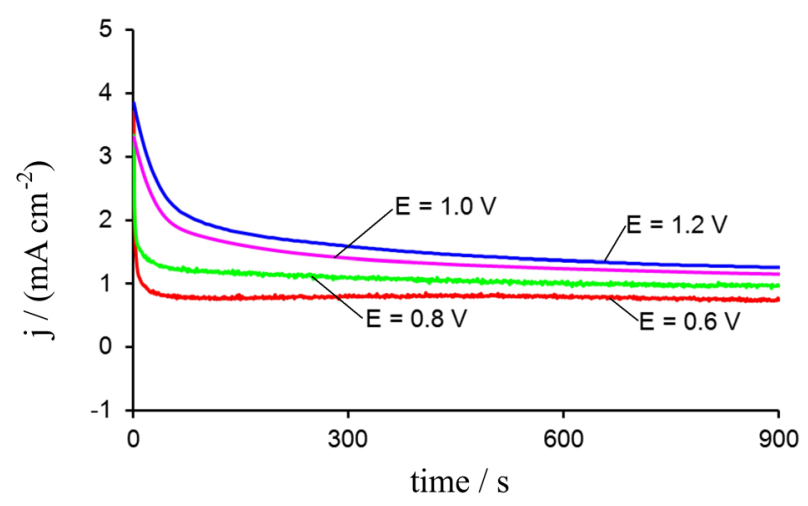

Figure 3. Chronoamperometric curves of PPy electrodeposition on aluminium in $\left\{0.1 \mathrm{~mol} \mathrm{~L}^{-1} \mathrm{H}_{3} \mathrm{PO}_{4}+0.5 \mathrm{~mol} \mathrm{~L}^{-1} \mathrm{Py}\right\}$ at different potentials: $0.6,0.8,1$ and $1.2 \mathrm{~V}$.

\section{Corrosion performance}

\section{Open circuit potential}

Figure 4 shows the open circuit potential against time for four samples of aluminium coated with PPy in $3 \% \mathrm{NaCl}$ aqueous medium: $\mathrm{PPy}$-coated $\mathrm{Al}$ with a thickness of 14, 28, 43 and $57 \mu \mathrm{m}$, signed as $\mathrm{PPy}_{14 \mu \mathrm{m}}, \mathrm{PPy}_{28 \mu \mathrm{m}}$, $\mathrm{PPy}_{43 \mu \mathrm{m}}$ and $\mathrm{PPy}_{57 \mu \mathrm{m}} / \mathrm{Al}$, respectively. The organic film was galvanostatically electrosynthesized with a current density of $3 \mathrm{~mA} \mathrm{~cm}^{-2}$.

Comparing identical plots for $\mathrm{Al}$ immersed in phosphoric acid during $24 \mathrm{~h}$ (signed as $\mathrm{Al}_{24 \mathrm{~h}}$ ) and bare $\mathrm{Al}$ polished (signed as $\mathrm{Al}_{\text {bare }}$ ), it could be deduced the influence of PPy and its thickness in the aluminium behavior. The thick PPy brings a large positive displacement of the electrode potential in comparison with the bare electrode. The aluminium potential $-927 \mathrm{mV}$ is shifted to values of around 140-210 $\mathrm{mV}$. On the other hand, the time of protection of $\mathrm{Al}$ by PPy closely depends on the coating thickness: (i) $\mathrm{PPy}_{14 \mu \mathrm{m}} / \mathrm{Al}$ is a very porous structure since the initial

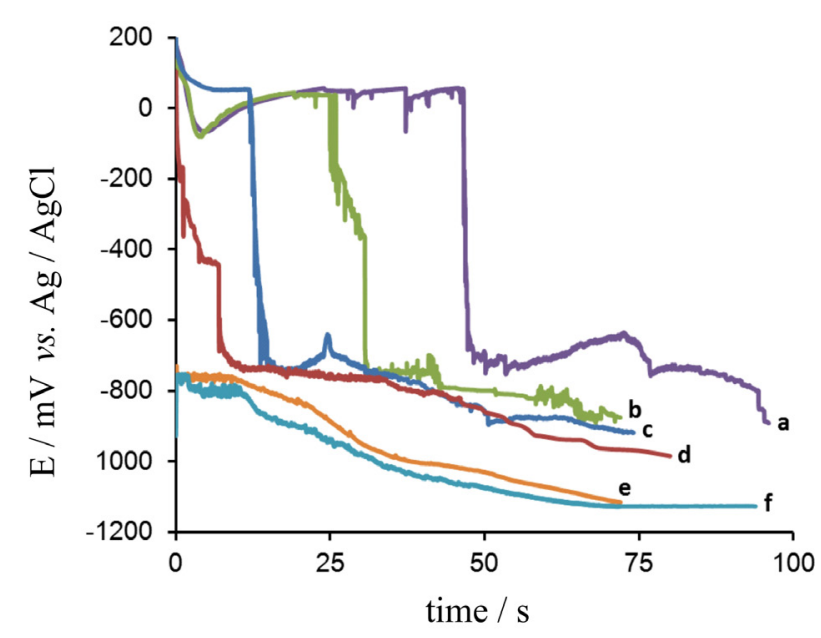

Figure 4. The open circuit potential evolution of different samples in 3\% NaCl: (a) $\mathrm{PPy}_{57 \mu \mathrm{m}} / \mathrm{Al}$, (b) $\mathrm{PPy}_{43 \mu \mathrm{m}} / \mathrm{Al}$, (c) $\mathrm{PPy}_{28 \mu \mathrm{m}} / \mathrm{Al}$, (d) $\mathrm{PPy}_{14 \mu \mathrm{m}} / \mathrm{Al}$, (e) $\mathrm{Al}_{24 \mathrm{~h}}$ and (f) $\mathrm{Al}_{\text {bare }}$.

potential of $104 \mathrm{mV}$ rapidly drops to a value of $-410 \mathrm{mV}$ in the time of $2 \mathrm{~h}$, which keeps it in a pseudo plateau approximately more $2 \mathrm{~h}$, and then fall steadily to values similar to the potential of aluminium; (ii) the $\mathrm{PPy}_{57 \mu \mathrm{m}} / \mathrm{Al}$, $\mathrm{PPy}_{43 \mu \mathrm{m}} / \mathrm{Al}$ and $\mathrm{PPy}_{28 \mu \mathrm{m}} / \mathrm{Al}$ maintain the electrode in passive region during 47,24 and $12 \mathrm{~h}$, respectively, then the protection breaks down and the potential quickly falls to $c a .750 \mathrm{mV}$ vs. $\mathrm{Ag} / \mathrm{AgCl}$; these electrodes are kept at this level of potential, respectively, for another 25,12 and $10 \mathrm{~h}$; finally the shape of the following part of the OCP curve becomes similar to that of $\mathrm{Al}_{\text {bare }}$ and $\mathrm{Al}_{24 \mathrm{~h}}$ for these three coating thickness, decreasing the potential over time.

Table 2 shows the evolution of the aluminium content in two solutions of sodium chloride during time for the $\mathrm{PPy}_{57 \mathrm{~mm}}$ /Al electrode: (i) test solution of OCP and (ii) fresh solution after performing the EIS test on the electrode.

Table 2. Evolution of the $\mathrm{Al}^{3+}$ concentration in solution during time in $3 \% \mathrm{NaCl}$ solutions of OCP and EIS tests for $\mathrm{PPy}_{57 \mu m} / \mathrm{Al}$ electrode. The concentrations were measured by AAS

\begin{tabular}{lcc}
\hline \multirow{2}{*}{ time $/ \mathrm{h}$} & \multicolumn{2}{c}{ Aluminium content $/\left(\mathrm{mg} \mathrm{L}^{-1}\right)$} \\
\cline { 2 - 3 } & OCP solution & EIS solution \\
\hline 24 & 0.295 & 0.770 \\
40 & 0.774 & 0.205 \\
115 & 0.796 & 0.041 \\
\hline
\end{tabular}

AAS: atomic absorption spectrophotometry.

The results indicate the following: (i) the aluminium content in the solution of OCP increased $c a$. two and a half times between 24 and $40 \mathrm{~h}$, and then almost stabilizes; (ii) the aluminium content in the solution of EIS after $24 \mathrm{~h}$ is two and a half times the solution of OCP, it reduces about 
three and a half times to $40 \mathrm{~h}$, and to about seven and a half times to $115 \mathrm{~h}$. These observations show that there is a blockage of the structure of PPy by insoluble compounds of aluminium, which promotes the corrosion resistance of the electrode.

On the basis of these results, it is assumed that the mechanism of protection required by the PPy is sketched in Figure 5. The interpretation of this mechanism is as follow:

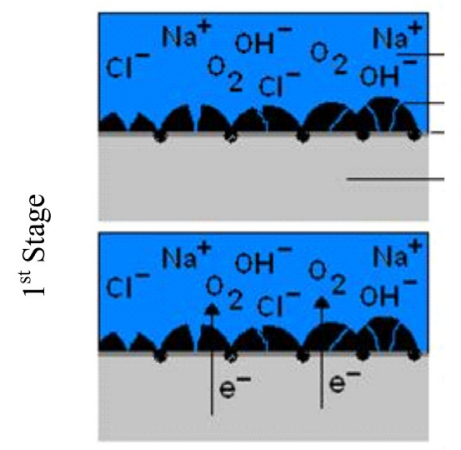

\author{
$\mathrm{NaCl}$ solution \\ PPy layer \\ Passivation layer \\ Al electrode \\ PPy reduction and \\ reoxidation \\ Ion exchange \\ $\mathrm{Cl}^{-}$by $\mathrm{H}_{2} \mathrm{PO}_{4}^{-}$
}

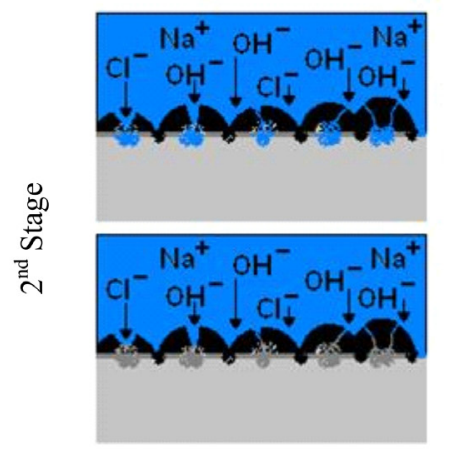

Breaking down of the passivation layer

Compounds formation in the PPy pinholes such as $\mathrm{Al}(\mathrm{OH}) \mathrm{Cl}^{+}, \mathrm{Al}(\mathrm{OH})_{2} \mathrm{Cl}$, $\mathrm{Al}(\mathrm{OH}) \mathrm{Cl}_{2}$

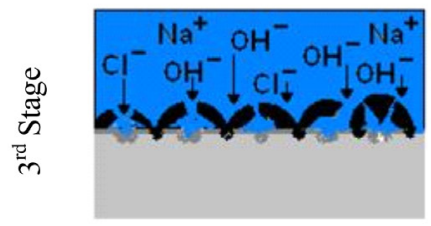

Coating delamination

$\mathrm{AlCl}_{3}, \mathrm{AlCl}_{4}^{-}, \mathrm{AlO}_{2}^{-}$

Figure 5. Scheme of the proposed protective mechanism of PPy coating on aluminium in $3 \% \mathrm{NaCl}$ solution.

During the first stage, the electrolyte diffuses through the pinholes of the PPy coating towards the aluminium surface. Meanwhile, an ion exchange phenomenon between the dihydrogenophosphate ion and chloride ion occurs through the PPy backbone. ${ }^{33,34}$

$$
\left(\mathrm{PPy}^{\mathrm{y}+} \mathrm{yH}_{2} \mathrm{PO}_{4}^{-}\right)_{\mathrm{n}}+\mathrm{nyCl}^{-} \rightarrow\left(\mathrm{PPy}^{\mathrm{y}+} \mathrm{yCl}^{-}\right)_{\mathrm{n}}+\mathrm{nyH}_{2} \mathrm{PO}_{4}^{-}
$$

This process prevents the progression of chloride ion towards the metal surface, and therefore its adverse pitting effect.

At the Al/PPy or Al/BL interfaces, corrosion of the aluminium takes place according to reactions 5 and 6 .
Anodic reaction: $2 \mathrm{Al} \rightarrow 2 \mathrm{Al}^{3+}+6 \mathrm{e}^{-}$

Cathodic reaction: $\frac{3}{2} \mathrm{O}_{2}+3 \mathrm{H}_{2} \mathrm{O}+6 \mathrm{e}^{-} \rightarrow 6 \mathrm{OH}^{-}$

The hydrated $\mathrm{Al}^{3+}$ ion undergoes now a very fast hydrolysis reaction to give mononuclear species and oxide/hydroxide salts, and/or phosphate salt by interacting with dihydrogenate ions: ${ }^{31,35}$

$$
\begin{aligned}
& \mathrm{Al}^{3+}+\mathrm{H}_{2} \mathrm{O} \rightarrow \mathrm{AlOH}^{2+}+\mathrm{H}^{+} \\
& 2 \mathrm{Al}^{3+}+4 \mathrm{H}_{2} \mathrm{O} \rightarrow 2 \mathrm{Al}(\mathrm{OH})_{2}^{+}+4 \mathrm{H}^{+} \\
& \mathrm{Al}^{3+}+3 \mathrm{H}_{2} \mathrm{O} \rightarrow \mathrm{Al}(\mathrm{OH})_{3}+3 \mathrm{H}^{+} \\
& 2 \mathrm{Al}(\mathrm{OH})_{3} \rightarrow \mathrm{Al}_{2} \mathrm{O}_{3}+3 \mathrm{H}_{2} \mathrm{O} \\
& \mathrm{Al}^{3+}+\mathrm{H}_{2} \mathrm{PO}_{4}^{-} \rightarrow \mathrm{AlPO}_{4}+2 \mathrm{H}^{+}
\end{aligned}
$$

In neutral (around $\mathrm{pH} 4-9$ ) noncomplexing solutions, the oxide passive film on aluminium has very low solubility. Its electronic conductivity is also very low. Hence, the redox reactions are blocked. Taking into account the thermodynamics, reactions 12 and $13, \mathrm{AlPO}_{4}$ seems to be preferentially produced instead of oxide film. Any aluminium oxide formed in the vicinity of the $\mathrm{Al} / \mathrm{BL}$ or $\mathrm{Al} / \mathrm{PPy}$ interface is converted to $\mathrm{AlPO}_{4}$ by the $\mathrm{H}_{2} \mathrm{PO}_{4}^{-}$released from reaction 4 .

$$
\begin{aligned}
& \mathrm{Al}_{2} \mathrm{O}_{3} \cdot \mathrm{H}_{2} \mathrm{O}_{\text {boehmite }}+2 \mathrm{H}_{2} \mathrm{PO}_{4}^{-}+2 \mathrm{H}^{+} \rightarrow 2 \mathrm{AlPO}_{4}+4 \mathrm{H}_{2} \mathrm{O} \\
& \Delta \mathrm{G}^{\mathrm{o}}=-4.4 \mathrm{~kJ} \mathrm{~mol}^{-1}
\end{aligned}
$$

$$
\begin{aligned}
& \mathrm{Al}_{2} \mathrm{O}_{3} \cdot 3 \mathrm{H}_{2} \mathrm{O}_{\text {gibssite }}+2 \mathrm{H}_{2} \mathrm{PO}_{4}^{-}+2 \mathrm{H}^{+} \rightarrow 2 \mathrm{AlPO}_{4}+6 \mathrm{H}_{2} \mathrm{O} \\
& \Delta \mathrm{G}^{\mathrm{o}}=-3.7 \mathrm{~kJ} \mathrm{~mol}^{-1}
\end{aligned}
$$

Németh et al. ${ }^{36}$ using in situ radiotracer technique concluded that phosphate ion adsorption on passive aluminium layer is a largely irreversible process, which may be indicative of an on-going surface transformation, i.e., oxide film growth incorporating phosphate ions from the solution.

The increased resistance to cathodic disbondment for PPy-coated aluminium is attributed to a displacement of the electrochemical interface where is processed the reaction 6 , from the metal/solution interface to the polymer solution interface.$^{37-39}$ Instead of reaction 6, we may have as cathodic reaction the PPy reduction.

$\left(\mathrm{PPy}^{\mathrm{y}+} \mathrm{yH}_{2} \mathrm{PO}_{4}^{-}\right)_{\mathrm{n}}+\mathrm{ny}^{-} \rightarrow(\mathrm{PPy})_{\mathrm{n}}+\mathrm{nyH}_{2} \mathrm{PO}_{4}^{-}$

With the polymer reduction, the diffusion of ions through the polymer becomes more difficult and the rate 
of further polymer reduction decreases. However, the PPy may be again reoxidized by the oxygen from the solution, ${ }^{40}$ i.e., PPy-coated acts as an electrocatalyst.

In the second stage, the PPy backbone does not have more capacity to support reaction 4 , and chloride ions from solution or $\left(\mathrm{PPy}^{y+} \mathrm{yCl}^{-}\right)_{\mathrm{n}}$ penetrate the interior of the oxide film under one of the following possibilities: (i) through oxygen vacancies, ${ }^{41}$ (ii) through the oxide film water channels $\mathrm{s}^{42}$ and (iii) localized film dissolution or thinning. ${ }^{43}$ The following reactions may be used to explain the pitting on metallic surface.

$$
\mathrm{AlOH}^{2+}+\mathrm{Cl}^{-} \rightarrow \mathrm{Al}(\mathrm{OH}) \mathrm{Cl}^{+}
$$

$$
\mathrm{Al}(\mathrm{OH}) \mathrm{Cl}^{+}+\mathrm{H}_{2} \mathrm{O} \rightarrow \mathrm{Al}(\mathrm{OH})_{2} \mathrm{Cl}+\mathrm{H}^{+}
$$

$$
\mathrm{Al}(\mathrm{OH}) \mathrm{Cl}^{+}+\mathrm{Cl}^{-} \rightarrow \mathrm{Al}(\mathrm{OH}) \mathrm{Cl}_{2}
$$

It is well known that pits mainly occur in halogen solutions. Hence, both acidification, reaction 16, and chloride ions are necessary for pit development. The $\mathrm{pH}$ is lower when the concentration of chloride is higher until a solid metal salt is formed. The aluminium nuclear magnetic resonance (NMR) spectrum of the solution extracted from artificial pits was found to be $\mathrm{Al}(\mathrm{OH})_{2} \mathrm{Cl}$ and $\mathrm{Al}(\mathrm{OH}) \mathrm{Cl}_{2} \cdot{ }^{44}$ Inside, the pits the $\mathrm{pH}$ was between 3 and 4 and the bulk was 11. Alavi and Cottis ${ }^{45}$ in simulated crevice measured an identical range of $\mathrm{pH}$ in part of the crevice, but within a deeper part the $\mathrm{pH}$ was 8 . On the other hand, the saturated solution of $\mathrm{Al}(\mathrm{OH})_{2} \mathrm{Cl}$ exhibits a $\mathrm{pH}=3 .{ }^{46}$ These chlorohydroxi aluminium compounds may explain the second plateau observed in the OCP curves.

The potential observed on this second plateau $(c a .-0.75 \mathrm{~V})$ is identical to that observed by Martins et al. ${ }^{47}$ and McCafferty, ${ }^{48}$ and matches with the value of the pitting potential provided by equation 18 established by Lowson. ${ }^{49}$

$\mathrm{E}_{\mathrm{p}}=-0.475-0.059 \log \left[\mathrm{Cl}^{-}\right] \mathrm{V} v s . \mathrm{NHE}$

In the third stage, the continuous incorporation of $\mathrm{Cl}^{-}$ ions in the transitory compounds, such as $\mathrm{Al}(\mathrm{OH}) \mathrm{Cl}_{2}$ and $\mathrm{Al}(\mathrm{OH})_{2} \mathrm{Cl}$, leads to the formation of anionic complexes.

$$
\begin{aligned}
& \mathrm{Al}(\mathrm{OH}) \mathrm{Cl}_{2}+\mathrm{Cl}^{-} \rightarrow \mathrm{AlCl}_{3}+\mathrm{OH}^{-} \\
& \mathrm{AlCl}_{3}+\mathrm{Cl}^{-} \rightarrow \mathrm{AlCl}_{4}^{-} \\
& \mathrm{Al}_{2} \mathrm{O}_{3} \cdot 3 \mathrm{H}_{2} \mathrm{O}+2 \mathrm{OH}^{-} \rightarrow 2 \mathrm{AlO}_{2}^{-}+4 \mathrm{H}_{2} \mathrm{O}
\end{aligned}
$$

$$
\mathrm{Al}_{2} \mathrm{O}_{3} \cdot \mathrm{H}_{2} \mathrm{O}+2 \mathrm{OH}^{-} \rightarrow 2 \mathrm{AlO}_{2}^{-}+2 \mathrm{H}_{2} \mathrm{O}
$$

The chemical dissolution of the passive film gives an explanation for coating delamination and the decrease of corrosion potential over time observed in the OCP curves.

\section{Linear polarization in $3 \% \mathrm{NaCl}$}

The coated electrodes have been obtained galvanostatically at $3 \mathrm{~mA} \mathrm{~cm}{ }^{-2}$ in $0.1 \mathrm{~mol} \mathrm{~L}^{-1}$ phosphoric acid solution containing $0.5 \mathrm{~mol} \mathrm{~L}^{-1}$ pyrrole monomer. The corrosion resistance of these coatings in comparison with $\mathrm{Al}$ electrode medium was estimated by applying different current densities in 3\% NaCl during 5 min, Table 3.

Table 3. Evolution of the $\mathrm{Al}^{3+}$ concentration in solution with the applied current density between 0.1 and $10 \mathrm{~mA} \mathrm{~cm}^{-2}$ during $5 \mathrm{~min}$ in $3 \% \mathrm{NaCl}$ solution. The concentrations were measured by AAS

\begin{tabular}{lccc}
\hline Applied & \multicolumn{3}{c}{$\left[\mathrm{Al}^{3+}\right] / \mathrm{ppm}$} \\
\cline { 2 - 4 } $\mathrm{j} /\left(\mathrm{mA} \mathrm{cm}{ }^{-2}\right)$ & bare $\mathrm{Al}$ & $\mathrm{Al} / \mathrm{PPy}(14 \mu \mathrm{m})$ & $\mathrm{Al} / \mathrm{PPy}(28 \mu \mathrm{m})$ \\
\hline 0.1 & n.d. & n.d. & n.d. \\
0.5 & n.d. & n.d. & n.d. \\
1 & 0.65 & 1.10 & n.d. \\
3 & 3.22 & 2.26 & n.d. \\
5 & 5.60 & 4.38 & n.d. \\
10 & 9.69 & 9.95 & n.d. \\
\hline
\end{tabular}

AAS: atomic absorption spectrophotometry; n.d.: not detected.

The results show the following: (i) the $\mathrm{Al}$ electrode corrosion is higher than the PPy/Al-coated; (ii) considering the potential at which the coating has been produced (Figure 2), the PPy is partially overoxidized that increases the resistance of the bilayer $\left(\mathrm{Al}_{2} \mathrm{O}_{3} / \mathrm{PPy}\right)$ structure on aluminium and therefore a better behavior against corrosion; (iii) the dissolution of aluminium decreases with coating thickness of PPy.

\section{Electrochemical impedance spectroscopy (EIS)}

The corrosion performances of the PPy/Al with different thickness and aluminium bare have been also investigated by EIS in $3 \% \mathrm{NaCl}$. The spectra at open circuit potential are presented in Figure 6a.

The shape of the impedance spectrum of Al bare (Figure 6b) displays two different processes. The first one is a capacitive loop at high frequencies related with the formation of the passive film during the induction time for pit nucleation, and the second one is a straight line inclining at $c a .60^{\circ}$ to the real axis at medium and low frequencies, as a Warburg-like response. Several researches showed that at prepitting stage, $\mathrm{Cl}^{-}$could slightly inhibit the anodic dissolution of aluminium during its incorporation under different compound forms such as $\mathrm{Al}\left(\mathrm{OH}_{2}\right) \mathrm{Cl}, \mathrm{Al}(\mathrm{OH})$ 

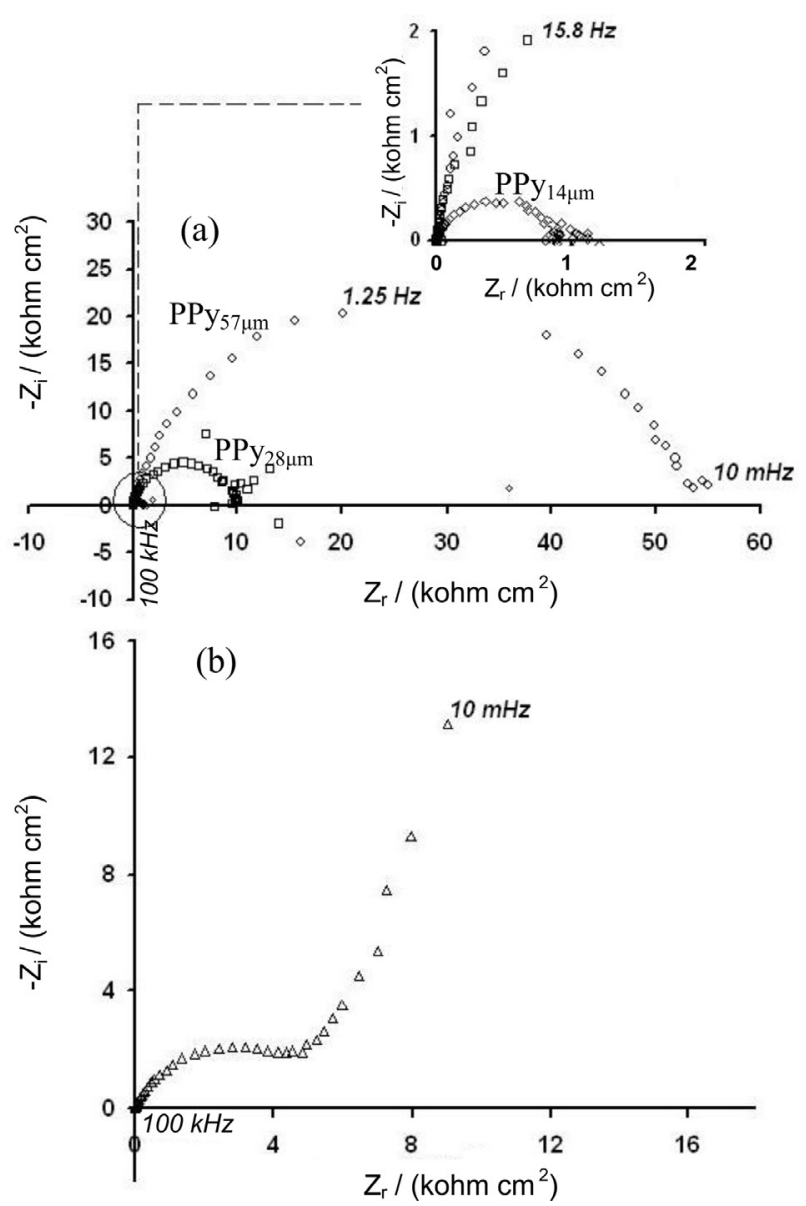

Figure 6. Nyquist plots recorded in $3 \% \mathrm{NaCl}$ at the time of immersion of: (a) $\mathrm{PPy}_{57 \mu \mathrm{m}} / \mathrm{Al}(\bigcirc), \mathrm{PPy}_{28 \mu \mathrm{m}} / \mathrm{Al}(\square)$ and $\mathrm{PPy}_{14 \mu \mathrm{m}} / \mathrm{Al}(\diamond)$ and (b) bare aluminium. Inset: magnification below $2 \mathrm{kohm} \mathrm{cm}^{2}$.

$\mathrm{Cl}_{2}$ and $\mathrm{AlCl}_{3} \cdot{ }^{44,50}$ After this stage, $\mathrm{AlCl}_{3}$ and $\mathrm{Al}(\mathrm{OH}) \mathrm{Cl}_{2}$ produced react with $\mathrm{Cl}^{-}$and forms the aluminium complex $\mathrm{AlCl}_{4}^{-}$. As a result of alkalization of the solution, reaction 19, it is also produced another chemically soluble ionic species, $\mathrm{AlO}_{2}^{-}$. Thus, the passivation film created on the aluminium can be cracked, which allows a high migration through the oxide film represented by Warbug impedance observed at instantaneous open circuit potential and after several hours of immersion in 3\% sodium chloride solution, Figure 7.

Arc Nyquist plots of $\mathrm{PPy} / \mathrm{Al}$ in $3 \% \mathrm{NaCl}$ solution show depressed semicircles at high and low frequencies, Figure 6a. This behavior may be assigned to the reactions at polymer/electrolyte and polymer/metal interface. The first behavior at high-frequencies is related to polymer film resistance $\left(\mathrm{R}_{\mathrm{f}}\right)$, and the second one at the middle and low-frequency region is attributed to charge transfer resistance $\left(\mathrm{R}_{\mathrm{ct}}\right)$. The diameter of the semicircles is equal to the polarization resistance $R_{p}$, including $R_{f}$ and $R_{c t}$. It is clearly seen from the spectra that the $R_{p}$ increases with increasing the PPy thickness. The spectra confirm that thicker PPy coating provides better corrosion protection of

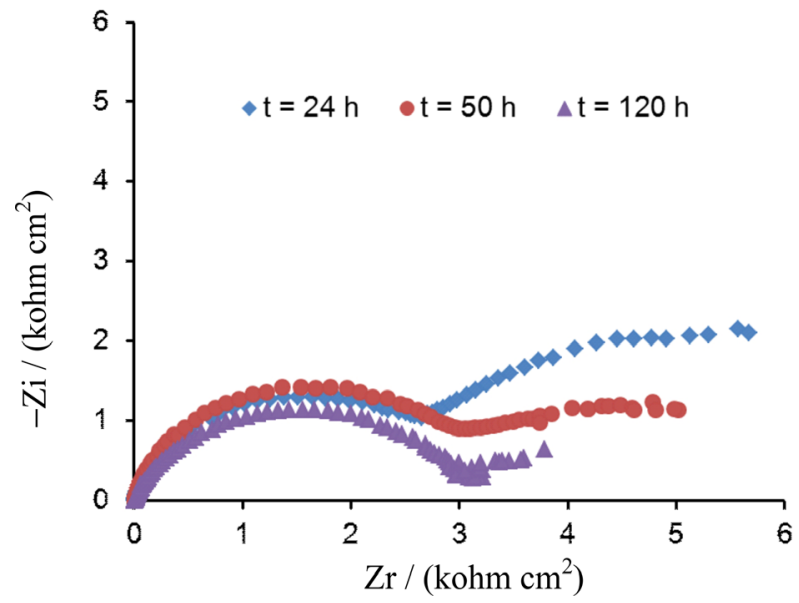

Figure 7. Nyquist plots recorded in $3 \% \mathrm{NaCl}$ on bare aluminium during the time.

aluminium in full agreement with the previous OCP and linear polarization studies.

\section{Conclusions}

The electrodeposition of PPy on aluminium has been achieved in phosphoric acid medium using potentiodynamic, galvanostatic and potentiostatic techniques. The protection of $\mathrm{Al}$ against corrosion is closely depended on the PPy thickness and its overoxidation state. Effectively, the time of corrosion inhibition in $3 \% \mathrm{NaCl}$ is longer with thicker PPy film in the basis of the results obtained by open circuit potential, linear polarization and electrochemical impedance spectroscopy. In addition to the parameters of the electrochemical techniques that determine the structure and overoxidation of PPy, according to the proposed mechanism for aluminium corrosion in $3 \% \mathrm{NaCl}$, the dopant dihydrogenophosphate ion has an important role on the corrosion behavior of aluminium coated with PPy synthesized from phosphoric acid medium.

\section{Acknowledgements}

We acknowledge the Portuguese Science and Technology foundation (FCT) for a post-doctoral fellow-ship SFRH/ BPD/26672/2006 and the Project POCTI/CTM/41136.

\section{References}

1. Zhou, J.; Duszczyk, J.; Korevaar, B. M.; J. Mater. Sci. 1991, 26, 3041.

2. Anand, S.; Srivatsan, T. S.; Wu, Y.; Lavemia, E. J.; J. Mater. Sci. 1997, 32, 2835.

3. Goni, J. V.; Rodrguez-Ibabe, J. M.; Urcola, J. J.; Key Eng. Mater. 1997, 127-131, 911. 
4. Wernick, S.; Pinner, R.; The Surface Treatment and Finishing of Aluminium and its Alloys; E. Eyrolles: Paris, 1962, p. 228-260.

5. Thompson, G. E.; Wood, G. C.; Treatise on Materials Science and Technology, Anodic Films on Aluminium; J. C. Scully: New York, 1983, p. 250-287.

6. Young, L.; Anodic Oxide Films; Academic Press: New York, 1961.

7. Wrzecian, M.; Pratique de L'oxydation Anodique et des Traitements Annexes sur L'aluminium et ses Alliages; Éditions B. P. I.: Paris, 1964.

8. Hoar, T. P.; Wood, G. C.; Electrochim. Acta 1962, 333.

9. Wernick, S.; Pinner, R.; Sheasby, P. G.; The Surface Treatment and Finishing of Aluminium and its Alloys, vol. 2, $5^{\text {th }}$ ed.; Finishing Publications Ltd.: Teddington Middlesex, England, 1996, ch. 6.

10. Hao, L.; Cheng, B. R.; Met. Finish. 2000, 98.

11. Wood, G. C.; Skeldon, P.; Thompson, G. E.; Shimizu, K. J.; Electrochem. Soc. 1996, 143, 74.

12. Zhang, J.-S.; Zhao, X.-H.; Zuo, Y.; Xiong, J.-P.; Surf. Coat. Technol. 2008, 202, 3149.

13. De Lae, J.; Terryn, H.; Vereecken, J.; Thin Solid Films 1998, $320,241$.

14. Thompson, G. E.; Thin Solid Films 1997, 297, 192.

15. Furneaux, R. C.; Thompson, G. E.; Wood, G. C.; Corros. Sci. 1978, $18,853$.

16. Jagminas, A.; Bigelienš, D.; Mikulskas, I.; Tomašiŭnas, R.; J. Cryst. Growth 2001, 233, 591.

17. Bazzaoui, M.; Bazzaoui, E. A.; Martins , J. I.; Martins, L.; Mater. Sci. Forum 2004, 455-456, 484.

18. Martins, J. I.; Reis, T. C.; Bazzaoui, M.; Bazzaoui, E. A.; Martins, L.; Corros. Sci. 2004, 46, 2361.

19. Bazzaoui, M.; Martins, J. I.; Bazzaoui, E. A.; Reis, T. C.; Martins, L.; J. Appl. Electrochem. 2004, 34, 815.

20. Beck, F.; Hülser, P.; J. Electroanal. Chem. 1990, 280, 159.

21. Cheung, K. M.; Bloor, D.; Stevens, G. C.; Polymer 1988, 29 , 1709.

22. Naio, K.; Takeda, M.; Kanno, H.; Sakakura, M.; Shimada, A.; Electrochim. Acta 2000, 45, 3413.

23. Saidman, S. B.; J. Electroanal. Chem. 2002, 537, 39.

24. Saidman, S. B.; Bessone, J. B.; J. Electroanal. Chem. 2002, $521,87$.

25. Akundy, G. S.; Iroh, J. O.; Polymer 2001, 42, 9665.

26. Bazzaoui, M.; Martins, J. I.; Reis, T. C.; Bazzaoui, E. A.; Nunes; M. C.; Martins, L.; Thin Solid Films 2005, 485, 155.
27. Bazzaoui, M.; Martins, J. I.; Costa; S. C.; Bazzaoui, E. A.; Reis, T. C.; Martins, L.; Electrochim. Acta 2006, 51, 2417.

28. Martins, J. I.; Costa, S. C.; Bazzaoui, M.; Goncalves, G.; Fortunato, E.; Martins, R.; Electrochim. Acta 2006, 51, 5802.

29. Martins, J. I.; Costa, S. C.; Bazzaoui, M.; Gonçalves, G.; Fortunato, E.; Martins, R.; J. Power Sources 2006, 160, 1471.

30. Lohrengel, M. M.; Mater. Sci. Eng. 1993, R11, 243.

31. Kuo, H.-S.; Tsai, W.-T.; Mater. Chem. Phys. 2001, 69, 53.

32. Dean, J. A.; Lange's Handbook of Chemistry, $2^{\text {nd }}$ and $15^{\text {th }}$ eds.; McGraw-Hill: New York, 1973 and 1999.

33. Koehler, S.; Ueda, M.; Efimov, I.; Bund, A.; Electrochim. Acta 2007, 52, 3040.

34. Bazzaoui, M.; Martins, J. I.; Bazzaoui, E. A.; Martins, L.; Machnikova, E.; Electrochim. Acta 2007, 52, 3568.

35. Guseva, O.; Schmutz, P.; Suter, T.; von Trzebiatowski, O.; Electrochim. Acta 2009, 54, 4514.

36. Németh, Z.; Gáncs, L.; Gémes, G.; Kilics, A.; Corros. Sci. 1998, 40, 2023.

37. Refait, P.; Abdelmoula, M.; Génin, J.-M. R.; Corros. Sci. 1998, 40, 1547.

38. Rammelt, U.; Nguyen, P. T.; Pieth, W.; Electrochim. Acta 2001, 46, 4251 .

39. Spinks, G. M.; Dominis, A. J.; Wallace, G. G.; Tallman, D. E.; J. Solid State Electrochem. 2002, 6, 85.

40. Yan, M.; Tallman, D. E.; Bierwagen, G. P.; Electrochim. Acta 2008, 54, 220.

41. Macdonald, D. D.; J. Electrochem. Soc. 1992, 139, 3434.

42. Bockris, J. O. M.; Kang, Y.; J. Solid State Electrochem. 1997, $1,17$.

43. Nguyen, T. H.; Foley, R. T.; J. Electrochem. Soc. 1980, 127, 2563.

44. Wong, K. P.; Alkire, R. C.; J. Electrochem. Soc. 1990, 137, 3010 .

45. Alavi, A.; Cottis, R. A.; Corros. Sci. 1987, 27, 443.

46. Vijh, A. K.; Corros. Sci. 1973, 13, 805.

47. Martins, N. C. T.; Silva,T. M.; Montemor, M. F.; Electrochim. Acta 2008, 53, 4754.

48. McCafferty, E.; Corros. Sci. 1995, 37, 481.

49. Lowson, R. T.; Aust. J. Chem. 1978, 31, 943.

50. Pyun, S. I.; Moon, S. M.; Ahn, S. H.; Kim, S. S.; Corros. Sci. 1999, $41,653$. 